\title{
Trianchoratus longianchoratus sp. n. (Monogenea: Ancyrocephalidae: Heteronchocleidinae) from Channa lucius (Osteichthyes: Channidae) in Peninsular Malaysia
}

\author{
W.B. Tan and L.H.S. Lim
}

Institute of Biological Sciences, University of Malaya, Kuala Lumpur, 50603, Malaysia

\begin{abstract}
One new and three previously described species of Trianchoratus Price et Berry, 1966 were collected from the gills of Channa lucius (Cuvier) and Channa striata (Bloch) from the Bukit Merah Reservoir, Perak and Endau-Rompin, Pahang, Peninsular Malaysia. They are Trianchoratus longianchoratus sp.n., T. malayensis Lim, 1986 and T. pahangensis Lim, 1986 from C. lucius, and T. ophicephali Lim, 1986 from C. striata. The new species differs from the Trianchoratus species hitherto described from channids and anabantoids in having two ventral anchors with a long curved inner root and one dorsal anchor with a curved inner root and lacking an outer root. A table summarizing the known species of heteronchocleidins (Trianchoratus, Eutrianchoratus and Heteronchocleidus) and Sundanonchus reported from fish hosts of different families (Channidae, Helostomatidae, Anabantidae and Osphronemidae) is provided.
\end{abstract}

Key words: Trianchoratus, Ancyrocephalidae, Heteronchocleidinae, Channa lucius, Channa striata, Anabantoidei, Channoidei, Malaysia

There are 26 species of Channa (Scopoli) (syn. Ophicephalus) and three species of Parachanna (Teugels et Daget) (syn. Ophicephalus) within the Channidae (see Li et al. 2006). In Peninsular Malaysia, channids are represented by seven Channa spp., namely C. lucius (Cuvier), C. striata (Bloch), C. marulioides (Bleeker), C. bankanensis (Bleeker), C. gachua (Hamilton-Buchanan), C. micropeltes (Cuvier et Valenciennes) and C. melasoma (Bleeker) (see Lee 1997). The channids are hosts to monogenean species belonging to Trianchoratus Price et Berry, 1966, Eutrianchoratus Paperna, 1969 and Sundanonchus Lim et Furtado, 1985 (see Lim 1997). Trianchoratus, Eutrianchoratus and Heteronchocleidus Bychowsky, 1957 have been assigned to the subfamily Heteronchocleidinae Price, 1968 (Ancyrocephalidae Bychowsky, 1937) (see Lim 1986, 1998). To date, there are 29 species of heteronchocleidine monogeneans (10 Trianchoratus spp., 9 Eutrianchoratus spp. and 10 Heteronchocleidus spp.) described from 16 freshwater fish species of channids (3 species) and anabantoids (13 species); the information is summarized in Table 1. A recent investigation on monogeneans from freshwater fish species of Peninsular Malaysia revealed the presence of one new and three previously described species of Trianchoratus on Channa lucius from the Bukit Merah Reservoir, Perak (7 individuals) and Endau-Rompin, Pahang (4 individuals) and also on C. striata from the Bukit Merah Reservoir (9 indi- viduals). Examinations of recently collected specimens of T. malayensis Lim, 1986, T. pahangensis Lim, 1986 and T. ophicephali Lim, 1986 revealed discrepancies in the latter two species which prompted the re-examinations of the type specimens of these three described species present in the parasite collection of the Zoological Department, University of Malaya (UMZD).

\section{MATERIALS AND METHODS}

Two species of Channa were obtained from the Bukit Merah Reservoir (Channa lucius and C. striata) and Endau-Rompin (C. lucius), Peninsular Malaysia. These fish were caught using hook and line. The monogeneans were removed from the gills and prepared for investigations of their soft and hard parts. Some specimens were flattened to varying degrees to best expose the soft anatomical structures and stained in Gomori's triple stain, following Lim (2006). Some specimens were flattened and mounted in modified ammonium picrate glycerine (Lim 1991) and later made into unstained permanent mounts in Canada balsam. The stained and unstained parasites were examined using both bright field and phase contrast optics. Images of the hard and soft body parts were captured using a Leica digital camera (Leica DFC320) and image analysis software (QWin Plus) and were drawn using a digitising tablet (WACOM) and Adobe Illustrator software. Measurements of the sclerotized hard-parts (both haptoral and reproductive) were made on flattened stained or unstained specimens cleared in ammonium picrate glycerine. The basic measurements taken are as indicated in Fig. 1 and are 
given as the mean and range (within parentheses) in micrometres. Illustrations of the hard-parts and a composite figure of the whole body of the new species are given.

The following type specimens of the three previously described Trianchoratus species from the parasite collection of the University of Malaya (UMZD) were re-examined: T. malayensis [31 specimens: UMZD(P)28, UMZD(P) 99(P)-129(P)], T. pahangensis $[50$ specimens: $\operatorname{UMZD}(\mathrm{P}) 27, \operatorname{UMZD}(\mathrm{P})$ 130(P)179(P)], and T. ophicephali [79 specimens: UMZD(P)26, UMZD(P) 180(P)-258(P)]. The haptoral hard-parts of the type specimens were measured using Leica QWIN imaging software for comparison.

Type specimens of the new species are deposited in the Natural History Museum, London (BMNH), the Helminthological Collection, Institute of Parasitology, Biology Centre of the Academy of Sciences of the Czech Republic, České Budějovice (HCIP) and the Muzium Zoologi Universiti Malaya, Kuala Lumpur (MZUM). Voucher specimens of the three previously described Trianchoratus species collected during the present study are deposited in the Natural History Museum, London (BMNH) and the Muzium Zoologi Universiti Malaya, Kuala Lumpur (MZUM).

\section{RESULTS}

A total of 101 specimens of Trianchoratus malayensis [vouchers MZUM(P)763(V)-863(V)], 136 specimens of $T$. pahangensis [vouchers MZUM(P)864(V)-872(V), MZUM(P)875(V)-999(V), BM(NH)2008.12.22.3], 250 specimens of T. ophicephali $[$ vouchers MZUM(P)1000(V) -1185(V), MZUM(P)1187(V)-1249(V), BM(NH)2008. 12.22.2], and 29 specimens of $T$. longianchoratus sp. n. [1 holotype $\mathrm{BM}(\mathrm{NH}) 2008.12 .22 .1,2$ paratypes HCIP (M-481) and 26 paratypes MZUM(P)737(P)-762(P)] were collected from C. lucius in Endau-Rompin (7 individuals) in 2002 and from C. lucius (4 individuals) and C. striata (9 individuals) in the Bukit Merah Reservoir in 2006 and 2008. Re-examinations of the type specimens of T. malayensis, T. pahangensis and T. ophicephali from C. lucius and C. striata revealed errors in the labelling of the figures in the original description of $T$. pahangensis and T. ophicephali. On page 39 of Lim (1986), figs. 50-55 and fig. 56 should have been labelled as $T$. pahangensis and figs. 57-62 as T. ophicephali.

\section{Trianchoratus longianchoratus sp. n. Fig. 1A-F}

Description. Body size 524 (371-677) × 137 (72-167). Eyespots 4 . Alimentary system consists of pharynx, short oesophagus and caeca confluent just anterior to haptor. Haptor slightly longer than wide, 119 (96-134) × 98 (81$114)$ in size. Dorsal anchors unequal: 1 vestigial anchor, comma-shaped, length 15 (13-19); 1 well-developed anchor, with indistinct outer root and long curved inner root 36 (33-38), inner length 44 (41-46), outer length 23 (21$26)$, point 23 (20-24) long, recurved. Two ventral anchors equally developed, inner length 54 (50-58), outer length 26 (25-27), long curved inner root 54 (50-57), outer root
4 (4-6) long, point 21 (20-23) long, recurved. Connecting bars absent. Marginal hooks 14 in number, length 15 (12-17). Testis dorsal to ovary; vas deferens arises from anterior margin of testis, crosses diagonally along dorsal field of body, loops around left caecum to ventral field. Copulatory organ 39 (36-43) long, consisting of large rounded initial part, coiled tube and accessory piece with proximal rod and more complex broad distal part. Ovary median; uterus extends anteriorly to uterine pore close to copulatory organ. Vitelline follicles co-extensive with intestinal caeca, confluent anteriorly, medially and posteriorly. Vagina comprising short tube with sclerotized, cuplike, dextral opening.

Type host: Channa lucius (Cuvier) (Channidae).

Type locality: Bukit Merah Reservoir, Perak, Malaysia.

Material studied: 29 specimens; 20 specimens measured.

Type specimens: Holotype BM(NH)2008.12.22.1;2 paratypes HCIP(M-481) and 26 paratypes MZUM(P)737(P)762(P).

Etymology: The specific appellation is derived from the long inner roots of the three well-developed anchors.

Differential diagnosis. There are 10 previously described species of Trianchoratus from channids and anabantoids (Table 1). This new species is very different from $T$. malayensis and T. pahangensis from C. lucius and $T$. ophicephali from $C$. striata in having anchors with long curving inner roots. In the three previously described species from channids, the inner roots of the developed anchors do not curve as distinctly. The vestigial dorsal anchor in the new species [15 (13-19) long, $\mathrm{n}=20$ ] is similar in shape and size to that of T. pahangensis [16 (1118), $\mathrm{n}=114$ ] but smaller than that of T. ophicephali $[19$ (17-21), $\mathrm{n}=95$ ] and T. malayensis [20 (15-25), $\mathrm{n}=83$ ]. The marginal hooks of the new species [15 (12-17) long, $\mathrm{n}=20]$ are similar in size to those of $T$. pahangensis [15 $(13-16), \mathrm{n}=114]$ but smaller than those of T. ophicephali [19 (18-19), $\mathrm{n}=95]$ and T. malayensis [20 (16-22), $\mathrm{n}=91]$.

The shape of the developed anchors with long curving inner roots also distinguishes this new species from the Trianchoratus species found on the anabantoids (Table 1). For example, the anchors of T. longianchoratus are different from those of T. acleithrium Price et Berry, 1966 from Helostoma temmincki (Cuvier), which are almost C-shaped with gently curved points, and from the almost C-shaped anchors with sharply recurved points of T. grandis Lim, 1986 from Anabas testudineus (Bloch). Basically, in the Trianchoratus spp. from other anabantoids, the roots of the ventral anchors are broad compared to the narrow slender roots of those species, including the new species, from channids.

The soft anatomical parts, particularly the reproductive organs, of this new species are similar to those of the three known species from channids but with minor differences, 


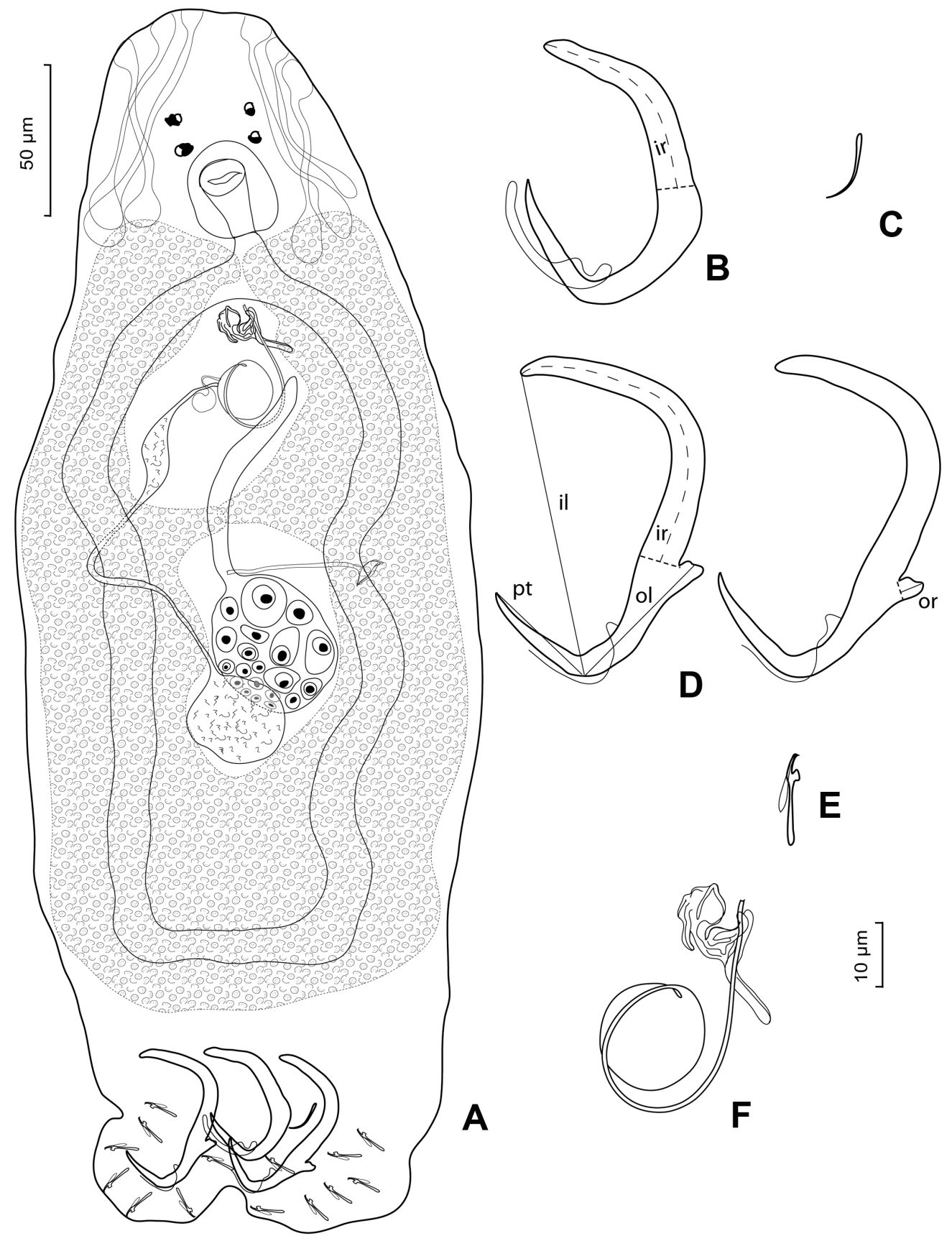

Fig. 1. Trianchoratus longianchoratus sp.n. A - composite drawing, dorsal view; B - dorsal anchor; $\mathbf{C}$ - vestigial dorsal anchor; D - ventral anchors; E - marginal hook; F - copulatory organ. Abbreviations: il - inner length; ir - inner root length; ol - outer length; or - outer root length; $\mathrm{pt}$ - point length.

particularly in the vagina, which is not as conspicuous as in the others. Trianchoratus spp. from channids possess larger vaginal opening and a longer vagina tube than the Trianchoratus spp. from anabantoids (see Lim 1986).

\section{DISCUSSION}

Including Trianchoratus longianchoratus there are now 11 species of Trianchoratus from channids (4 Trianchoratus spp.) and anabantoids (7 Trianchoratus spp.)
(Table 1). With the exception of T. kearni Agrawal et Bhatnagar, 1994, from the Indian Anabas testudineus, the other 10 species are from Southeast Asian anabantoids and channids (Table 1). Of the seven species of Channa in Peninsular Malaysia, monogeneans have been only recorded on C. micropeltes, $C$. lucius and C. striata (Table 1), although our field records reveal that C. gachua, C. marulioides and C. bankanensis have all been examined (Lim, personal observations). The presence of 
Tan, Lim: Trianchoratus longianchoratus sp. n.

Table 1. List of monogenean (Trianchoratus, Eutrianchoratus, Heteronchocleidus and Sundanonchus) species from channid and anabantoid fishes.

\begin{tabular}{|c|c|c|c|c|}
\hline & Host species $^{1}$ & Monogenean species & Locality & Reference \\
\hline \multicolumn{5}{|l|}{ Channoidei } \\
\hline \multirow[t]{12}{*}{ Channidae } & $\begin{array}{l}\text { Channa striata } \\
\text { (Ophicephalus striatus) }\end{array}$ & T. ophicephali Lim, 1986 & Malaysia & Lim 1986 \\
\hline & $\begin{array}{l}\text { Channa lucius } \\
\text { (Ophicephalus lucius) }\end{array}$ & T. pahangensis Lim, 1986 & Malaysia & Lim 1986 \\
\hline & $\begin{array}{l}\text { C. lucius } \\
\text { (O. lucius) }\end{array}$ & T. malayensis Lim, 1986 & Malaysia & Lim 1986 \\
\hline & C. lucius & T. longianchoratus sp. $\mathrm{n}$. & Malaysia & Present study \\
\hline & $\begin{array}{l}\text { Parachanna obscura } \\
\text { (Ophicephalus obscurus) }\end{array}$ & E. magnum Paperna, 1969 & Ghana, Africa & Paperna 1969 \\
\hline & $\begin{array}{l}\text { P. obscura } \\
\text { (O. obscurus) }\end{array}$ & E. minutus Paperna, 1969 & Ghana, Africa & Paperna 1969 \\
\hline & $\begin{array}{l}\text { P. obscura } \\
\text { (O. obscurus) }\end{array}$ & E. imbachi Dossou et Euzet, 1984 & Benin, Africa & Dossou and Euzet 1984 \\
\hline & P. obscura & E. chibami Bilong Bilong, Euzet et Birgi, 1994 & Cameroon, Africa & Bilong Bilong et al. 1994 \\
\hline & P. obscura & E. malleus Bilong Bilong, Euzet et Birgi, 1994 & Cameroon, Africa & Bilong Bilong et al. 1994 \\
\hline & Channa micropeltes & S. micropeltis Lim et Furtado, 1985 & Malaysia & Lim and Furtado 1985 \\
\hline & C. micropeltes & S. foliaceus Lim et Furtado, 1985 & Malaysia & Lim and Furtado 1985 \\
\hline & C. micropeltes & S. tomanorum Kritsky et Lim, 1995 & Malaysia & Kritsky and Lim 1995 \\
\hline \multicolumn{5}{|l|}{ Anabantoidei } \\
\hline \multirow[t]{2}{*}{ Helostomatidae } & $\begin{array}{l}\text { Helostoma temmincki } \\
\text { (H. rudolfi })\end{array}$ & T. acleithrium Price et Berry, 1966 & Southeast Asia ${ }^{2}$ & Price and Berry 1966 \\
\hline & H. temmincki & T. acleithrium Price et Berry, 1966 & Malaysia & Lim 1986 \\
\hline \multirow[t]{11}{*}{ Anabantidae } & Anabas testudineus & T. grandis Lim, 1986 & Malaysia & Lim 1986 \\
\hline & A. testudineus & T. gussevi Lim, 1986 & Malaysia & Lim 1986 \\
\hline & A. testudineus & T. parvulus Lim, 1986 & Malaysia & Lim 1986 \\
\hline & A. testudineus & T. kearni Agrawal et Bhatnagar, 1994 & India & Agrawal and Bhatnagar 1994 \\
\hline & Ctenopoma kingsleyae & H. ctenopomae Paperna, 1969 & Ghana, Africa & Paperna 1969 \\
\hline & C. kingsleyae & H. ouemensis Euzet et Dossou, 1975 & Africa & Euzet and Dossou 1975 \\
\hline & C. kingsleyae & H. tuzetae Euzet et Dossou, 1975 & Africa & Euzet and Dossou 1975 \\
\hline & C. kingsleyae & H. adjanohouni Euzet et Dossou, 1975 & Africa & Euzet and Dossou 1975 \\
\hline & C. kingsleyae & H. ouemensis Euzet et Dossou, 1975 & Africa & Euzet and Dossou 1975 \\
\hline & C. kingsleyae & H. tuzetae Euzet et Dossou, 1975 & Africa & Euzet and Dossou 1975 \\
\hline & C. kingsleyae & H. adjanohouni Euzet et Dossou, 1975 & Africa & Euzet and Dossou 1975 \\
\hline \multicolumn{5}{|l|}{ Osphronemidae } \\
\hline \multirow[t]{4}{*}{ Belontiinae } & Belontia hasselti & E. cleithrium Lim, 1989 & Malaysia & Lim 1989 \\
\hline & B. hasselti & E. distensigenitalis Lim, 1989 & Malaysia & Lim 1989 \\
\hline & B. hasselti & E. fusiformis Lim, 1989 & Malaysia & Lim 1989 \\
\hline & B. hasselti & E. inequalis Lim, 1989 & Malaysia & Lim 1989 \\
\hline \multirow[t]{4}{*}{ Macropodinae } & Trichopsis vittata & H. buschkielli Bychowsky, 1957 & Malaysia & Lim 1986 \\
\hline & Macropodus opercularis & H. buschkielli Bychowsky, 1957 & China & Bychowsky 1957 \\
\hline & Macropodus chinensis & H. buschkielli Bychowsky, 1957 & China & Tchang and Ji 1980 \\
\hline & M. chinensis & H. magnihamatus Tchang et Ji, 1980 & China & Tchang and Ji 1980 \\
\hline \multirow[t]{6}{*}{ Luciocephalinae } & Trichogaster leerii & T. leerium Lim, 1986 & Malaysia & Lim 1986 \\
\hline & Trichogaster trichopterus & T. trichogasterium Lim, 1986 & Malaysia & Lim 1986 \\
\hline & Colisa labiosa & H. gracilis Mizelle et Kritsky, 1969 & India & Mizelle and Kritsky 1969 \\
\hline & Colisa lalius & $\begin{array}{l}\text { H. asymmetricus Majumdar, Ramchandrula, } \\
\text { Trupati et Agrawal, } 1988\end{array}$ & India & Majumdar et al. 1988 \\
\hline & C. lalius & $\begin{array}{l}\text { H. stunkardi Majumdar, Ramchandrula, } \\
\text { Trupati et Agrawal, } 1988\end{array}$ & India & Majumdar et al. 1988 \\
\hline & Colisa fasciatus & H. lucknowensis Agarwal et Bhatnagar, 1997 & India & Agarwal and Bhatnagar 1997 \\
\hline
\end{tabular}

${ }^{1}$ Valid names following FishBase (Froese and Pauly 2008); in parentheses, synonym names used in the original sources.

${ }^{2}$ Fish specimens were obtained from Cordell Farm Supply Co., Milledgeville, Georgia, USA and listed as from Sumatra, Borneo, Java, Malaya and Thailand. 
T. longianchoratus on C. lucius from Bukit Merah, Perak, but not on this host from Endau-Rompin or Tasek Bera (the type locality for T. malayensis and T. pahangensis) (Lim 1986), indicates that the habitat is an important factor in parasite distribution.

All of the Trianchoratus species described to date have morphologically similar copulatory organs and differ mainly in the shapes and sizes of their haptoral armaments, particularly in the three well-developed anchors (Lim 1986). Basically, those species from the anabantoids and channids can be distinguished by the general shape of the developed anchors. Some species from anabanto- ids have comparatively longer and more sharply recurved anchor points in comparison to those from channids. The vestigial dorsal anchor in all species of Trianchoratus, Heteronchocleidus and Eutrianchoratus is commashaped.

Acknowledgements. The authors would like to thank Mr. K.S. Liew for collecting the fish hosts, recovering and preparing the monogeneans for analyses and Dr. David Gibson for help in procuring relevant papers and for help with the manuscript. This paper forms part of the $\mathrm{PhD}$ programme of the first author and is supported by a research grant (FRGS) from the University of Malaya, Kuala Lumpur to the corresponding author.

\section{REFERENCES}

Agarwal N., Bhatnagar S. 1997: A monogenean Heteronchocleidus lucknowensis n. sp. of the family: Ancyrocephalidae Bychowsky, 1973; subfamily: Heteronchocleidinae Price, 1968. Indian J. Helminthol. 14: 5-8.

Agrawal N., Bhatnagar S. 1994: A new monogenean of the family: Ancyrocephalidae Bychowsky, 1937; subfamily: Heteronchocleidinae Price, 1968. J. Parasitol. Appl. Anim. Biol. 3: 117-120.

Bilong Bilong C.F., Euzet L., Birgi E. 1994: Deux nouveaux Eutrianchoratus Paperna, 1969 (Monogenea, Ancyrocephalidae), parasites branchiaux de Parachanna obscura (Gunther, 1861) (Teleostei, Channidae), au Cameroun. Parasite 1: 357-362.

Bychowsky B.E. 1957: Monogenetic trematodes, their systematics and phylogeny. English translation by P.C. Oustinoff and W.J. Hargis, Jr. (Eds.). Graphic Arts Press, Washington, D.C., 627 pp.

Dossou C., Euzet L. 1984: Monogenea of the genus Eutrianchoratus Paperna, 1969 gill parasites from Ophicephalus obscurus from Benin (Africa). Bull. Soc. Zool. Fr. 109: 239-247.

Euzet L., Dossou C. 1975: Parasites de poisson d'eau du Dahomey. I. Especes nouvelles du genre Heteronchocleidus (Monogenea) parasites d'Anabantidae. Bull. Mus. Natl. Hist. Nat., Paris. 3: 23-24.

Froese R., Pauly D. (Eds.) 2009: FishBase. World Wide Web electronic publication, www.fishbase.org, 2/2009.

KRITSKY D.C., Lim L.H.S. 1995: Phylogenetic position of Sundanonchidae (Platyhelminthes: Monogenoidea: Dactylogyridea), with report of two species of Sundanonchus from toman, Channa micropeltes (Channiformes: Channidae), in Malaysia. Invertbr. Biol. 114: 285-294.

LEE P.G.J. 1997: Systematics of Southeast Asian snakeheads using molecular and morphological data. Unpublished Ph.D. Thesis, National University of Singapore, $232 \mathrm{pp}$.

Li X., Musikasinthorn P., Kumazawa Y. 2006: Molecular phylogenetic analyses of snakeheads (Perciformes: Channidae) using mitochondrial DNA sequences. Ichthyol. Res. 53: 148-159.
Lim L.H.S. 1986: New species of Trianchoratus Price et Berry, 1966 (Ancyrocephalidae) from Malayan anabantoid fishes. Parasitol. Hung. 19: 31-42.

Lim L.H.S. 1989: Eutrianchoratus species (Heteronchocleidinae, Monogenea) from a Malaysian freshwater fish, Belontia hasselti (Anabantoidei). Helminthologia 26: 249-258.

Lim L.H.S. 1991: Three new species of Bychowskyella Achmerow, 1952 (Monogenea) from Peninsular Malaysia. Syst. Parasitol. 19: $33-41$

Lim L.H.S. 1997: Sundaic monogeneans and Gondwana. In: T. Flegel and I.H. MacRae (Eds.), Diseases in Asian Aquaculture III. Fish Health Section, Asian Fisheries Society, Manila, pp. 161-166.

Lim L.H.S. 1998: Diversity of monogeneans in Southeast Asia. Int. J. Parasitol. 28: 1495-1515.

Lim L.H.S. 2006: Diplectanids (Monogenea) on the archerfish Toxotes jaculatrix (Pallas) (Toxotidae) off Peninsular Malaysia. Syst. Parasitol. 64: 13-25.

Lim L.H.S., Furtado J.I. 1985: Sundanonchus g. n. (Monogenea, Tetraonchoididae) from two Malaysian freshwater fishes. Folia Parasitol. 32: 11-19.

Majumdar S., Ramchandrula A., Trupati B.G., Agrawal S.M 1988: Studies on two new forms of Heteronchocleidinae (Monogenea) from Colisa lalius at Raipur I. Indian J. Helminthol. 40: 78-86.

Mizelle J.D., Kritsky D.C. 1969: Studies on monogenetic trematodes. XXXIX. Exotic species of Monopisthocotylea with the proposal of Archidiplectanum gen. n. and Longihaptor gen. n. Am. Midl. Nat. 81: 370-386.

PAPERNA I. 1969: Monogeneans of the subfamily Heteronchocleidinae Price, 1968 (Dactylogyridae) from African freshwater fish. Parasitology 59: 557-561.

Price C.E., Berry W.S. 1966: Trianchoratus, a new genus of Monogenea. Proc. Helminthol. Soc. Wash. 33: 201-203.

TChAng C.Y., Ji G.L. 1980: A new species of monogenetic trematode of the genus Heteronchocleidus from freshwater fishes. Acta Zootaxon. Sin. 5: 240-241.

Accepted 30 March 2009 